\title{
Analýza balancování stoje na rukou
}

\author{
Analysis balanced handstands
}

\section{Petr Hedbávný, Dušan Hupka, Jana Sklenař́íková}

\section{Abstrakt}

\author{
Fakulta sportovních studií Masarykovy univerzity, Brno
}

$V$ rámci našeho př́spěvku jsme se zaměřili na analýzu balancování ve stoji na rukou, jakožto jedné ze základních pohybových struktur sportovni gymnastiky. Jeji specifičnost je determinována z mechanického hlediska výškou těžiště, velikosti opěrné plochy a celkovou rovnovážnou polohou, ve které udržujeme stabilitu. Tímto výzkumem se zabývalo mnoho autori̊, jsou však neucelené a bez aplikace do praxe.

Cílem projektu byla optimalizace nácviku stoje na rukou v závislosti na strategii udržování rovnováhy v této labilni statické pohybové struktuře.

Do výzkumu jsme použili synchronizaci 3D kinematické analýzy pomocí př́stroje SIMI Motion, stabilometrie a elektromyografii EMG, které nám odhalili vnitřní podstatu vnějšiho projevu techniky. Jednalo se o prípadovou studii, kde byl testovanou osobou gymnasta z žákovské kategorie a zaměřili jsme se na změny úhlu v kyčelním kloubu (,,rameno - kyčel - koleno“) a ramenním kloubu (,zápěstí-rameno-kyčel“) ve spojitosti se svalovou aktivitou sledovaných svalů a svalových skupin. Právě aplikací těchto poznatkư v praxi můžeme optimalizovat nácvik, který je v některých př́padech zdlouhavý.

\begin{abstract}
The research was focused on analyzing balancing in handstand, as one of the fundamental physical structure sports gymnastics. With this research dealt many authors, but without application in practice.Its specificity is determined from the mechanical point of gravity height, the size of the support surface and the overall equilibrium position in which maintain stability.

The aim of the project was to optimize the training of standing on their hands, depending on the strategy of maintaining a balance in this unstable static physical structure.

For a comprehensive analysis of handstands is utilized synchronized 3D kinematic analysis, stabilomathric measuring and EMG, which we were reveal the inner essence of outer performance of technique. It was a case study and the tested person was a gymnast of student category and we focused on changes in the angle of the hip joint ("shoulder - hip - knee") and shoulder joint ("wrist - shoulder - hip") in connection with the muscle activity observed muscles and muscle groups. Now the application of this knowledge in practice, we can optimize the training, which in some cases lengthy.
\end{abstract}

Kličová slova: analýza, stoj na rukou, rovnováha, gymnastika

Key words: analysis, handstand, balance, gymnastics

\section{ÚVOD}

Stoj na rukou je základní pohybovou strukturou v systému sportovně gymnastických činností. Představuje statickou labilní rovnovážnou polohu. Její specifičnost je determinována z mechanického hlediska výškou těžiště, velikostí opěrné plochy a celková obtížnost rovnovážné polohy, ve které udržujeme stabilitu. V neposlední řadě i atypickým postavením těla (střemhlav). Strategiemi udržování rovnováhy ve stoji na rukou se zabývalo více autorů, jejich názory však nejsou jednotné.

Nashner a McCollum (1985) uvádí, že konfigurace stoje na rukou je jiná než ve vzpřímeném stoji, protože jsou namísto tř́ zapojeny čtyři klouby (zápěstí, lokty, ramena a kyčle) a to vyžaduje specifickou posturální koordinaci. Taktéž Asseman a kol. (2004) je stejného názoru, když tvrdí, že udržení stoje na rukou je komplexnější, nebot' vyžaduje účast ne tří, ale čtyř kloubů.

Z hlediska strategie udržování rovnováhy ve stoji na rukou Sobery a Siedlacka (2007) zjistili nejvýraznější 
korekce v zápěstním kloubu: „, Regulace rovnováhy při stoji na rukou je uskutečňována podobně jako při stoji, tj. skrz prememistěni COP směrem k prstům nebo zápěstnímu kloubu v sagitální rovině nebo vpravo či vlevo $v$ rovině frontální. Udržení rovnováhy ve stoji na rukou vyžaduje maximální vyrovnávání v zápěstním kloubu. Regulace rovnováhy v této nepřirozené pozici se děje zejména skrz zvětšeni tlaku prstů na podložku jako odpověd' na pohyb těžiště směrem k prstưm nebo zvětšením tlaku pod zápěstním kloubem při pohybu těžiště k němu “.

Yeadon a Trwartha (2003) potvrzují nejvýznamnější činnost v zápěstí, kdy jsou perturbace v sagitální rovině vyrovnávané flexory a extenzory zápěstí se synergeticky pracujícími ramenními klouby a kyčlemi zabezpečujícími zachování fixované konfigurace těla. Rotace v zápěstí s rotacemi v ramenou a kyčlích obecně pracující ve stejném směru jako je směr rotace v zápěstí. Tyto výsledky jsou shodné s výsledky Kerwina a Trewartha (2001), kteří zjistili, že rotace v zápěstích, ramenou a kyčlích významně korelují s posunem těžiště, přičemž byl pohyb $\mathrm{v}$ zápěstí dominantní.

Výsledky práce Gautiera (2007), ve které analyzoval strategii udržování rovnováhy ve stoji na rukou u gymnastů, ukazují značný pohyb v ramenou $\left(8,56^{\circ}\right)$ a zápěstích $\left(12,39^{\circ}\right)$, lokty se téměř nepohybovaly $\left(1,21^{\circ}\right)$, ale dosáhly max. výchylky, kyčle se sotva pohnuly $\left(0,88^{\circ}\right)$. Jinou techniku zahrnující flexi v loketním kloubu zaznamenali Slobounov a Newell (1996). Podle Yeadona a Trwartha (2003) je tato flexe pravděpodobně využívána až po neúspěchu udržení rovnováhy pomocí „strategie zápěsti““. Gautier (2007) vysvětluje, že flexe loketních kloubů umožňuje gymnastům rychle snížit polohu těžiště v př́padě extrémní nerovnováhy, stejně jako tuto funkci plní u vzpřímeného postoje kolena. Dochází tak k větší toleranci výkyvu a je umožněno opětovné nabytí rovnováhy. Uspořádání ve stoji na rukou je tedy podobné jako u vzpřímeného postoje s tím, že funkce zápěstí je podobná funkci kotníků, lokty jsou obdobou kolen a ramena obdobou kyčlí.

Jak je z odkazů výše patrné, mnoho autorů ve svých analýzách monitoruje stabilitu ve stoji na rukou bez komplexního pohledu na strategii balancování. Synchronizace stabilometrie, EMG a 3D kinematické analýzy nám odhalí vnitřní podstatu vnějšího projevu techniky. Právě aplikací těchto poznatků v praxi budeme moci optimalizovat nácvik, který je v některých př́padech zdlouhavý. Př́íčnou bývá unifikovaná metodika aplikovaná na všechny věkové skupiny bez ohledu na pohlaví cvičence.

Tento př́spěvek vznikl v rámci projektu specifického výzkumu na podporu grantových projektů na FSpS, kdy jsme provedli komplexní biomechanickou analýzu synchronizací 3D kinematické analýzy, stabilometrických měření a EMG.

\section{METODIKA}

Cílem př́spěvku byla analýza balancování stoje na rukou v závislosti na udržování rovnováhy v této labilní statické pohybové struktuře. Práci jsme zaměřili jako př́ípadovou studii a měření jsme provedli na výkonnostním gymnastovi. Proband, kterého jsme testovali, byl ve věku 12 let z TJ Sokol Brno I., který závodí v mládežnické kategorii. Jeho výška je $150 \mathrm{~cm}$, hmotnost $34 \mathrm{~kg}$. Gymnastice se věnuje od pěti let. Trénuje $5 \mathrm{x}$ týdně v gymnastické tělocvičně a pravidelně se účastní krajských i republikových soutěží.

Provedli jsme tato synchronizovaná měření: 3D kinematickou analýzu, stabilometrii a povrchovou elektromyografii. Na cvičence jsme umístili elektrody přenosného přístroje EMG, které snímaly napětí při zapojení jednotlivých svalů. Jednalo se o osmivýstupový elektromyograf EMG - Mie medici research ltd. s prŕslušenstvím - snímací elektrody od firmy Unilect, referenční jednorázové EMG elektrody od firmy Eurotrade, dále počítač se softwarem MyoDat na zobrazení a uložení získaných dat.

Snímací elektrody jsme při měření umístili na bř́šška svalů, abychom minimalizovali riziko, že by byl měřený signál ovlivněn elektrickou aktivitou okolních svalů. Sledovali jsme amplitudy křivek, které se měnily v závislosti na svalovém napětí během statické výdrže ve stoji na rukou.

Povrchovou elektromyografíi jsme sledovali aktivitu těchto svalů (obr. 1):

$1-\mathrm{m}$. deltoideus clavicularis

2 - m. deltoideus scapularis

3 - m. erector spinae $4-\mathrm{m}$. rectus abdominis

$5-\mathrm{m}$. triceps brachii

$6-\mathrm{m}$. biceps brachii
7 - m. flexor carpi radialis

8 - m. extensor carpi ulnaris 


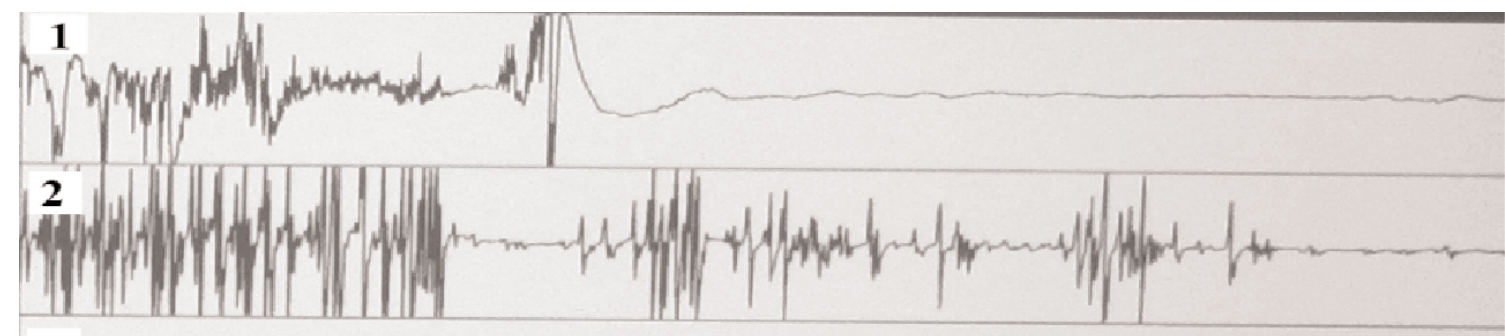

3

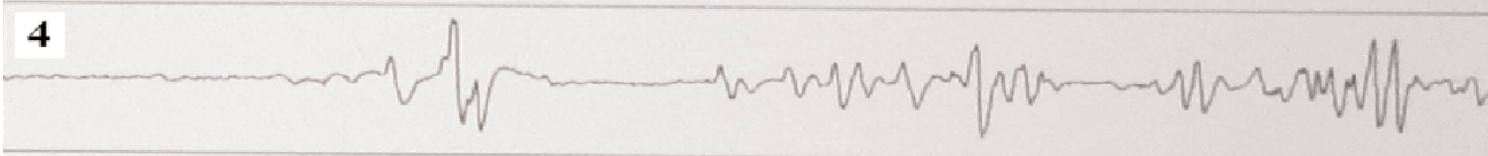

5

\section{6}

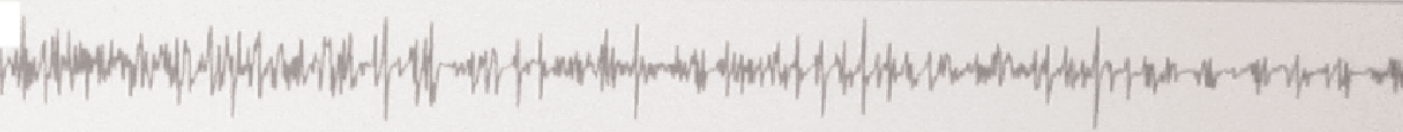

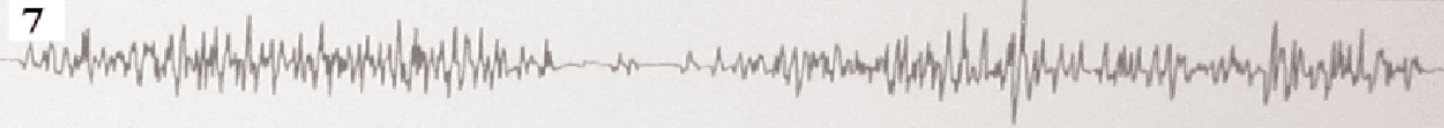

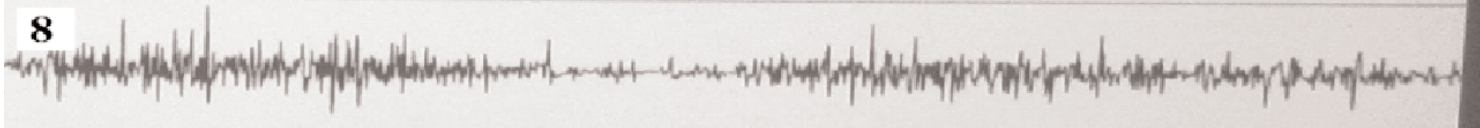

Obr. 1. Aktivita sledovaných svalů během měrení

\section{SIMI Motion}

Pro kinematickou analýzu jsme použili dvě vysokofrekvenční synchronizované kamery Basler A602fc (100 $\mathrm{Hz}$ ). Před pořízením 3D záznamu jsme označili na těle důležité body, které souvisejí s pohybem: hlava, levé a pravé rameno, levý a pravý loket, levé a pravé zápěstí, levý a pravý distální článek prostředníku na rukách, levá a pravá kyčel, levé a pravé koleno, levý a pravý kotník. Na tyto části těla jsme gymnastovi připevnili reflexní terčíky, které nám umožnily jednodušší rozpoznání pohybů v jednotlivých částech záznamu.

Z 3D kinematické analýzy jsme vyhodnocovali průběh úhlu v kyčelním kloubu (koleno - kyčel - rameno) a v ramenním kloubu (kyčel - rameno - loket). Zde je třeba upřesnit, že SIMI systém vyhodnocuje mezi segmenty vždy ten menší úhel, tedy s hodnotou do $180^{\circ}$. Rostoucí hodnoty úhlu v ramenním kloubu odpovídají extenzi v tomto kloubním spojení, klesající hodnoty pak flexi. Opačně je tomu však u kloubu kyčelního, kdy je tento úhel měřen přes hýždě. Rostoucí hodnoty tedy odpovídají flexi v kyčelním kloubu, neboli vysazení pánve, klesající hodnoty extenzi, neboli protlačení pánve. Pro jasnost jsou tyto úhly naznačeny v obr. 3.

Technické parametry př́strojů pro 3D:

- minimálně dvě kamery (Basler A602fc $100 \mathrm{hz}$ se současným snímání záběrů, optické osy by měly být v úhlu mezi 60 a 120 stupni

- kalibrační systém tvořený prostorovým 3D objektem (kvádr, krychle). Pozice rohů tohoto 3D objektu musí být známá 


\section{Stabilometrie}

Použitá stabilometrická plošina od firmy BERTEC - FORCE PLATE FP6090-15, o velikosti 60cm x 90cm má vysokou vlastní frekvenci a nosnost 10000N.

\section{Popis výzkumu}

Jakmile byly všechny přístroje na testované osobě (TO) nachystané a synchronizované s počítačem (obr. 2), nechali jsme TO na horizontální pohyblivé desce předvést stoj na rukou. Začali jsme měřit ve chvíli, kdy se TO dostala do rovnovážné polohy (obr. 3).
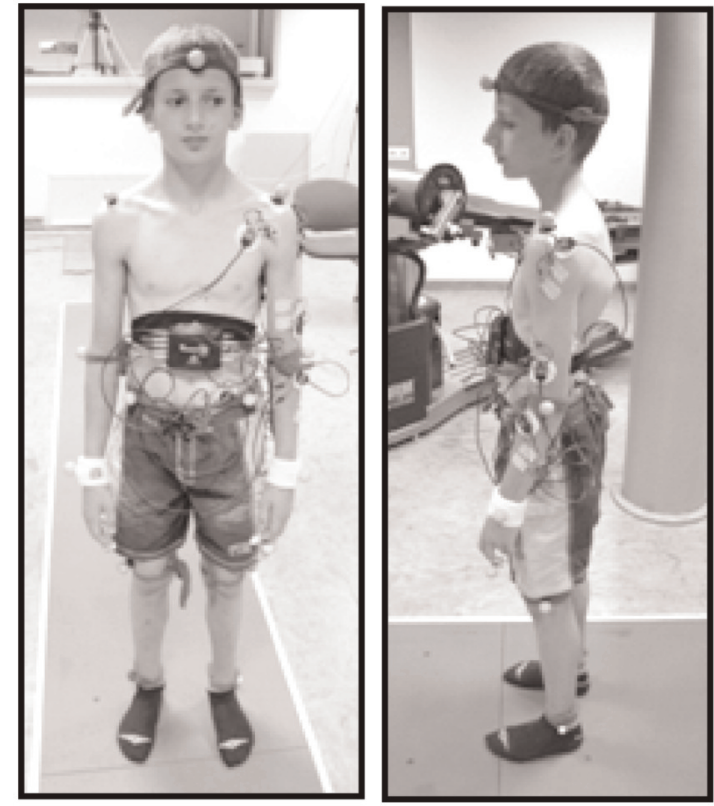

Obr. 2. Schéma zapojení reflexních bodi̊ pro kinematickou analýzu a elektrod pro EMG na stabilometrické plošině
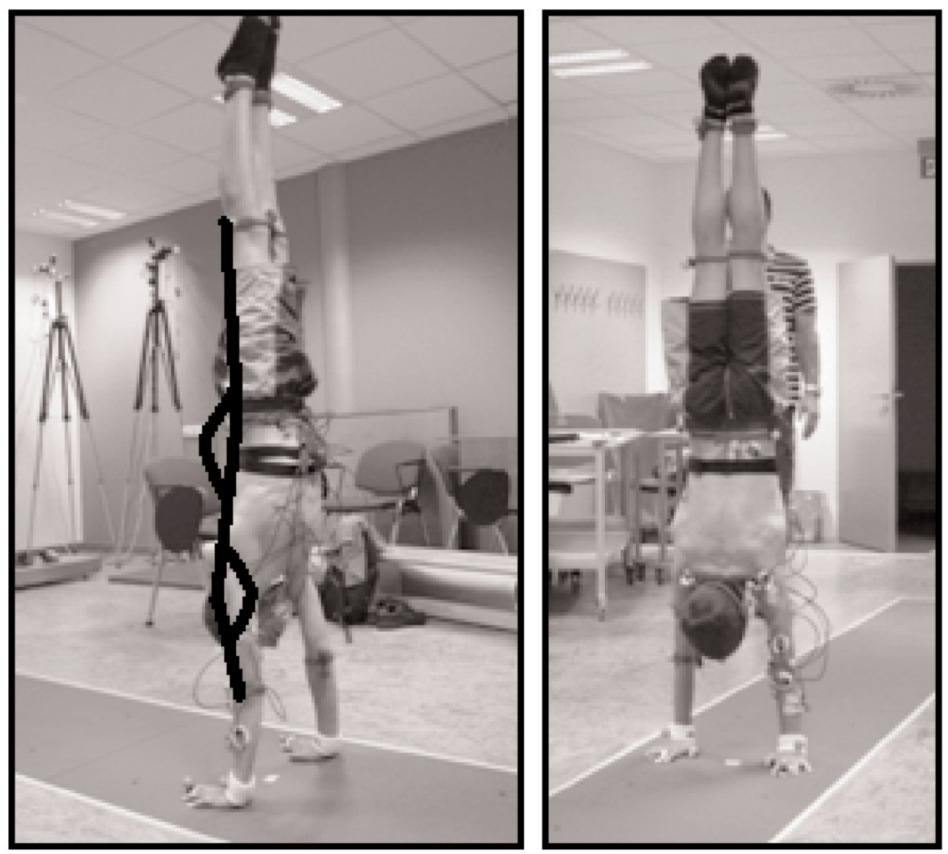

Obr. 3. TO měrená ve stoji na rukou 


\section{VÝSLEDKY}

Na obrázku 4 je křivka COP (Center of presure), která se mění v závislosti na balancování TO v předozadní a pravolevé rovině během stoje na rukou.

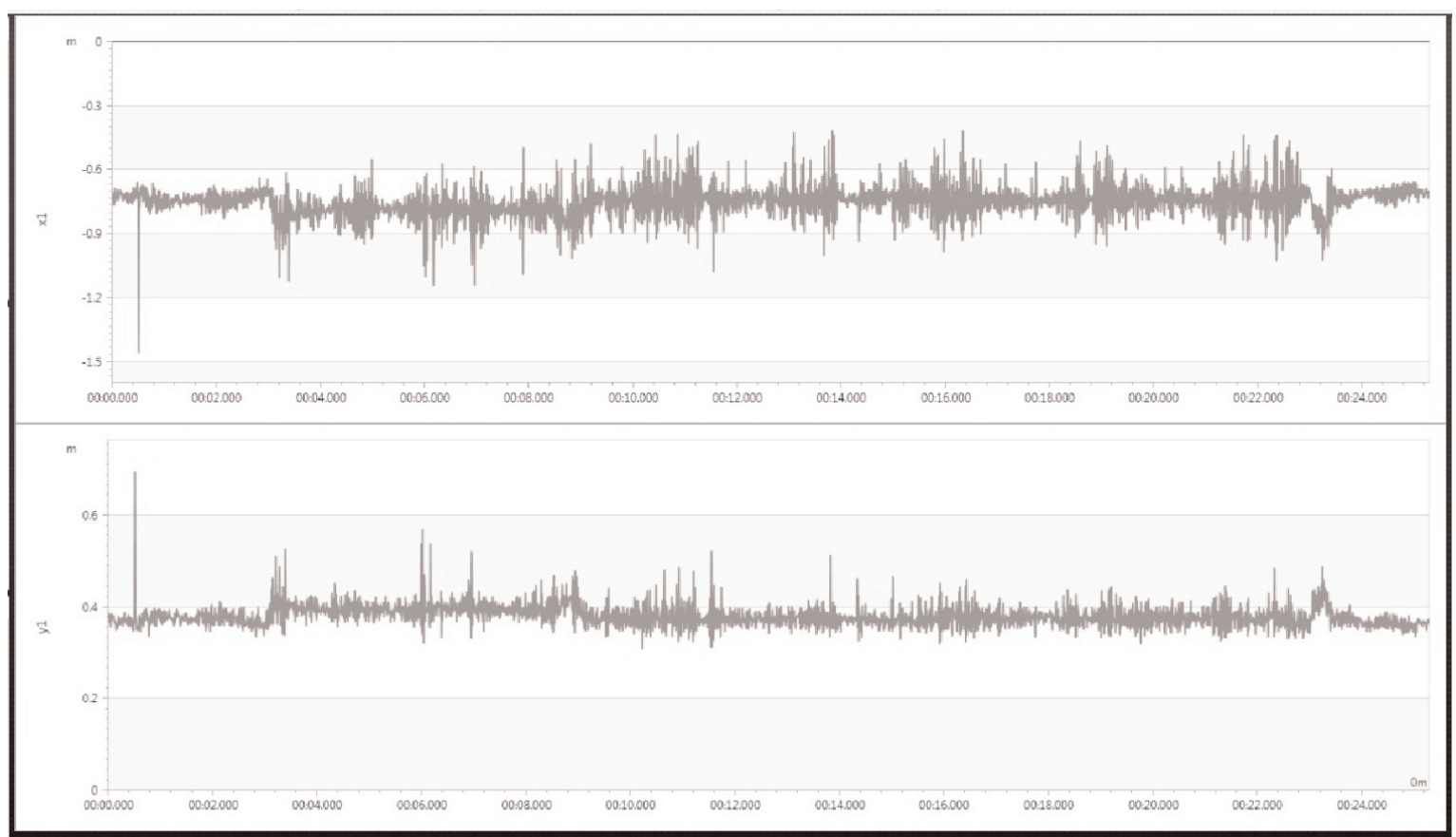

Obr. 4. Výchylky COP-nahoře v předozadni ose, dole v pravolevé ose

Výsledky stabilometrických měření podle našeho předpokladu ukazují, že rozsah výchylek COP v předozadní ose byl výrazně větší, než jejich rozsah v ose pravolevé. $Z$ toho důvodu se podrobněji zajímáme korekčními pohyby souvisejícími s posunem COP nad prsty a nad kořeny dlaní.

1. Výslednice změn úhlu v kyčelním kloubu (,rameno - kyčel - koleno“) ve spojitosti se svalovou aktivitou sledovaných svalů a svalových skupin (obr. 5), přičemž čísla 1 až 18 označují hraniční hodnoty, kde se úhel v důsledku balancování měnil.

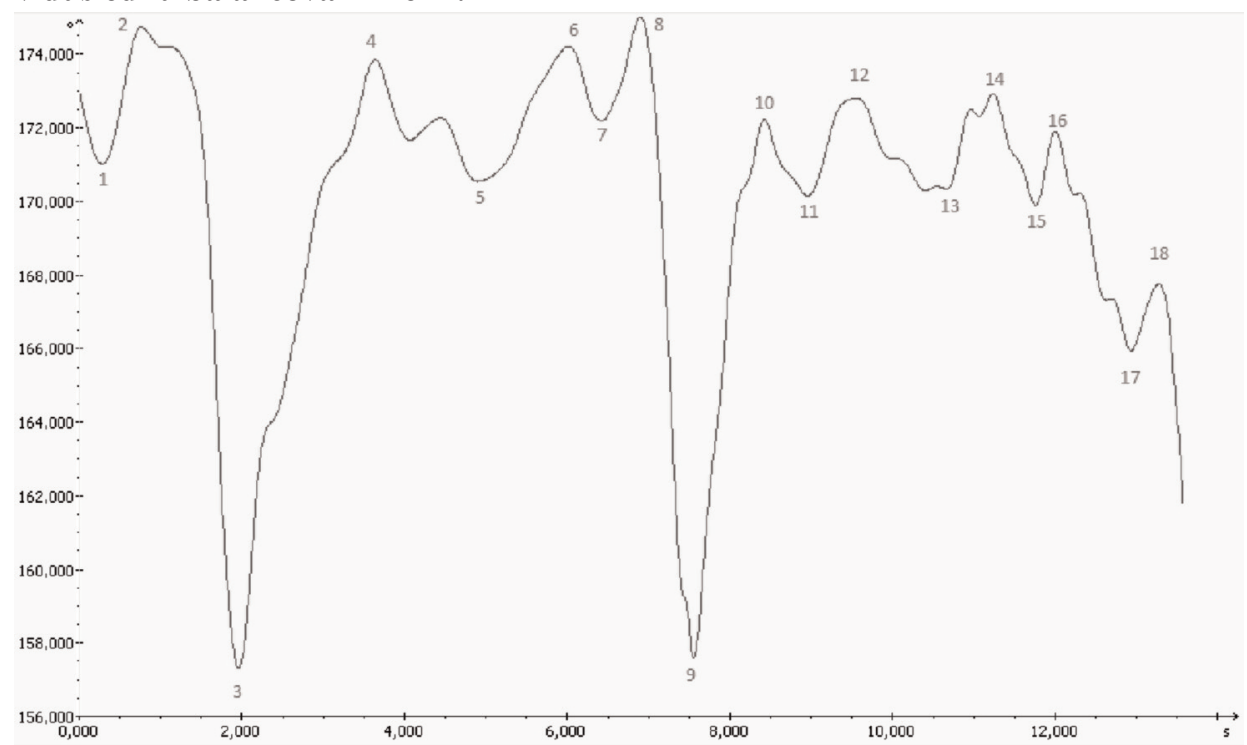

Obr. 5. Graf zobrazujicí změny velikosti úhlu „rameno - kyčel - koleno“ 
Tab. 1. Hodnoty úhlu „rameno - kyčel - koleno“ př́slušné $k$ jednotlivým číselným označením v grafu na obrázku č. 4.

\begin{tabular}{|c|c|c|}
\hline bod & hodnota úhlu $\left(^{\circ}\right.$ ) & Čas $(\mathbf{s})$ \\
\hline $\mathbf{1}$ & 171,022 & 0,280 \\
\hline $\mathbf{2}$ & 174,736 & 0,759 \\
\hline $\mathbf{3}$ & 157,320 & 1,959 \\
\hline $\mathbf{4}$ & 173,868 & 3,637 \\
\hline $\mathbf{5}$ & 170,547 & 4,897 \\
\hline $\mathbf{6}$ & 174,220 & 6,016 \\
\hline $\mathbf{7}$ & 172,197 & 6,416 \\
\hline $\mathbf{8}$ & 175,003 & 6,905 \\
\hline $\mathbf{9}$ & 157,591 & 7,555 \\
\hline $\mathbf{1 0}$ & 172,233 & 8,424 \\
\hline $\mathbf{1 1}$ & 170,148 & 8,954 \\
\hline $\mathbf{1 2}$ & 172,807 & 9,553 \\
\hline $\mathbf{1 3}$ & 170,332 & 10,663 \\
\hline $\mathbf{1 4}$ & 172,925 & 11,232 \\
\hline $\mathbf{1 5}$ & 169,900 & 11,762 \\
\hline $\mathbf{1 6}$ & 171,909 & 12,002 \\
\hline $\mathbf{1 7}$ & 165,940 & 12,931 \\
\hline $\mathbf{1 8}$ & 167,760 & 13,281 \\
\hline
\end{tabular}

Do výsledků jsme zaznamenali časové úseky zapojených svalů a jejich úhlové změny v kyčelním kloubu. Z vybraných hodnot změn úhlu jsme sestavili krabicový graf (obr. 6), který nám znázorňuje maximální a minimální velikosti úhlů a také medián.

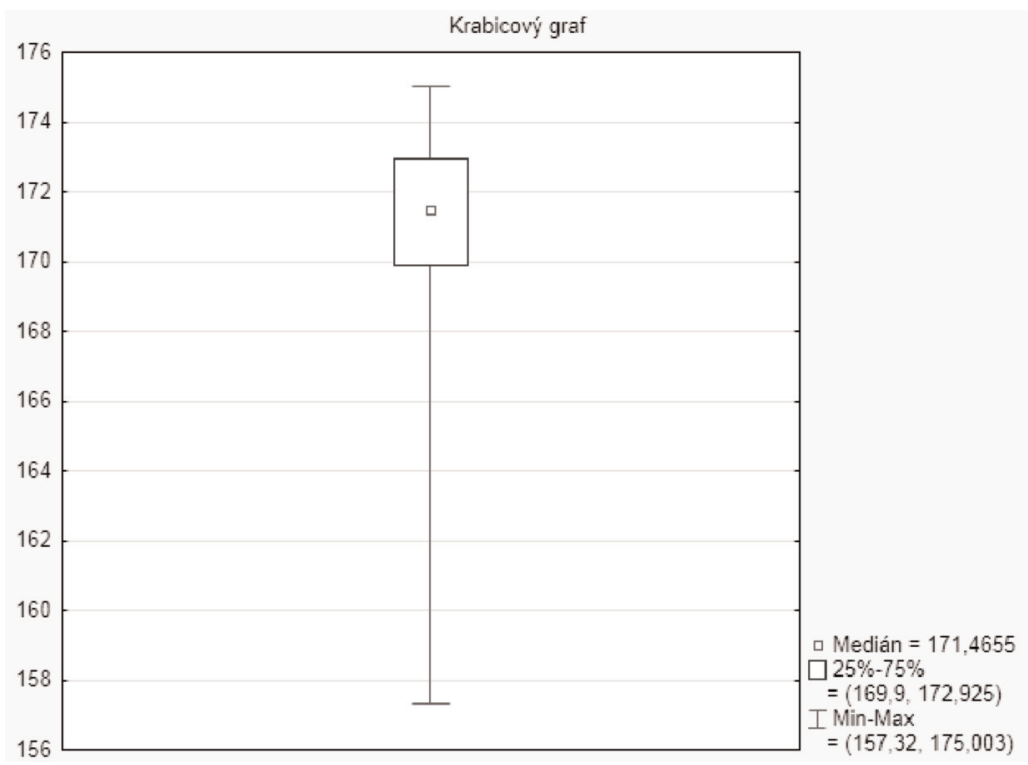

Obr. 6. Krabicový graf pro vizualizaci rozložení dat ve zkoumaném vzorku

Ze zjištěných údajů jsme vyhodnotili, že maximální úhel v segmentech „zápěstí - rameno - kyčel“ byl $175^{\circ}$ a minimální $157,32^{\circ}$. Medián má hodnotu $171,46^{\circ}$ a spíše se blíží k hodnotě maximálního úhlu. Následně přibližujeme pouze ty mikrofáze, ve kterých došlo $\mathrm{k}$ větším změnám. 


\section{1-2}

Na obrázku č. 4 a body označené č. 1-2 a v časovém úseku od 0,280 s do 0,759 s, kdy dochází ke zvětšování daného úhlu, vykazují významnou aktivní práci tyto ze sledovaných svalů:
m. rectus abdominis
$0,500-1,386 s$
m. erector spinae
$0,063-0,496 \mathrm{~s}$
m. triceps brachii
$0,089-10,666 s$

M. Triceps je neustále aktivní v důsledku potřeby napjatých loktů. Aktivita $m$. Rectus abdominis následuje po ukončení aktivity $m$. Erector spinae, teda nepracují současně, ale antagonisticky vyrovnávají svou práci.

\section{2-3}

Výrazný pokles hodnoty úhlu zaznamenáváme v čase 0,759 až 1,959 , kdy se úhel zmenšil až o $17,416^{\circ}$. Zpočátku pozvolné klesání přechází do ostré změny.
m. deltoideus (p. clavicularis)
$0,558-0,982 \mathrm{~s}$
m. deltoideus (p. scapularis)
$0,699-0,868 \mathrm{~s}$
m. flexor carpi radialis
$0,767-0,824 s$
$0,896-0,964 \mathrm{~s}$
m. extensor carpi ulnaris
$0,732-1,098 \mathrm{~s}$
$1,494-1,643 \mathrm{~s}$
$1,671-1,807 \mathrm{~s}$
m. erector spinae
$0,940-2,555 \mathrm{~s}$

Od 0,982 s přestáva pracovat $m$. deltoideus (p. clavicularis) a spolu s pracujícím $m$. deltoideus ( $p$. scapularis) se zapíná i $m$. erector spinae. Celou dobu je aktivní také $m$. rectus abdominis, až na krátou přestávku mezi 1,386 a 1,440 sekundou. Také neustále aktivní je $m$. triceps brachií, co vysvětlují napjaté lokty. Avšak zapojují se také $m$. flexor carpi radialis a $m$. extensor carpi ulnaris.

\section{5-6}

V časovém úseku od 4,897 s do 6,016 s, znovu dochází ke zvětšování daného úhlu, tedy nepatrné extenzi kyčle
m. deltoideus (p. clavicularis)
m. deltoideus (p. scapularis)
m. extensor carpi ulnaris
m. flexor carpi radialis
m. rectus abdominis
m. erector spinae

$5,283-6,277 \mathrm{~s}$

$4,443-5,155 \mathrm{~s}$

$5,591-6,442 \mathrm{~s}$

$5,335-5,418 \mathrm{~s}$

$5,213-7,553 \mathrm{~s}$

$4,409-5,131 \mathrm{~s}$

Je vidět vystř́ídání práce antagonistů $m$. deltoideus (p. clavicularis) proti $m$. deltoideus ( $p$. scapularis), $m$. rectus abdominis proti $m$. erector spinae a taktéž $m$. extensor carpi ulnaris proti $\mathrm{m}$. flexor carpi radialis, kdy práce jednoho začíná vyrovnávat tělo až po ukončení práce svalů protichůdného. Proband tedy nedrží balanc stálým napětím v obou skupinách svalů, ale zapíná antagonisty až poté, co je stabilita těla narušena prací jedné svalové skupiny. 
8-9

Druhý výrazný pokles hodnoty úhlu vidíme v čase 6,905 až 7,555 s, kdy se zmenšil až o $17,412^{\circ}$. Hodnota je téměř stejná jako v prvním př́padě, ovšem průběh tohoto poklesu je nárazový, bez předchozí postupnosti klesání.

m. extensor carpi ulnaris

m.biceps brachii

m. rectus abdominis

m. erector spinae

$$
\begin{array}{r}
6,800-7,093 s \\
7,159-7,200 s \\
7,234-7.486 s \\
7,127-7,186 s \\
7,321-7,858 s \\
5,213-7,553 s \\
6,904-7,885 s
\end{array}
$$

Při běžné aktivitě $m$. rectus abdominis a $m$. erector spinae vidíme výraznější práci paží na aktivitě $m$. biceps brachii a více krátkých zapojení $m$. extensor carpi ulnaris, čímž proband vyrovnával balancování do zadní roviny.

\section{2-13}

V časovém úseku od 9,553 s do 10,663 s, kdy dochází ke zvětšování daného úhlu a to zejména zapojením svalů $\mathrm{m}$. rectus abdominis a $\mathrm{m}$. erector spinae.

m. rectus abdominis

m. erector spinae

$$
\begin{aligned}
& 7,775-10,356 s \\
& 10,492-10,551 s \\
& 9,657-9,821 s \\
& 10,009-10,453 s \\
& 10,502-10,676 s
\end{aligned}
$$

\section{4-15}

V časovém úseku od 11,232 s do 11,762 s, kdy docházelo již k malým výchylkám v úhlech, byly v krátkých intervalech zapojené skoro všechny námi sledované svalové skupiny.
m. deltoideus (p. clavicularis)
m. deltoideus (p. scapularis)
m. flexor carpi radialis
m. extensor carpi ulnaris
m. triceps brachii
$m$. rectus abdominis
m. erector spinae

$10,746-12,521 \mathrm{~s}$

$10,003-11,598 s$

$11,625-11,746 s$

$11,567-11,874 \mathrm{~s}$$$
10,975-11,575 \mathrm{~s}
$$$$
10,693-14,477 \mathrm{~s}
$$$$
10,695-12,691 \mathrm{~s}
$$$$
11,380-11,538 \mathrm{~s}
$$$$
11,667-11,699 \text { s }
$$

Naše př́padová studie byla zaměřena na rozbor stability ve stoji na rukou po dobu 10 sekund, tudíž po tomto časovém intervalu jsme již dále výsledky neanalyzovali, nebot' proband již věděl, že splnil časový interval a jeho volní vlastnosti mohly způsobit, že se již nesoustředil na výkon tak, jak bychom očekávali.

Na základě získaných výsledků jsme nenašli žádnou výraznou, neboli významnou př́mou spojitost mezi prací sledovaných svalů a změnami úhlu ,rameno - kyčel - koleno“ na sledovaném probandovi. Z toho usuzujeme, že mechanizmy korigující daný úhel jsou ovládány vnitřním svalovým systémem, nebo svaly jinými, než jsme sledovali. 
2. Změny úhlu v ramenním kloubu („zápěstí - rameno - kyčel“) v spojitosti se svalovou aktivitou sledovaných svalů a svalových skupin (obr. 7), kde čísla 1 až 13 označují hraniční hodnoty, kde se úhel v důsledku balancování měnil.

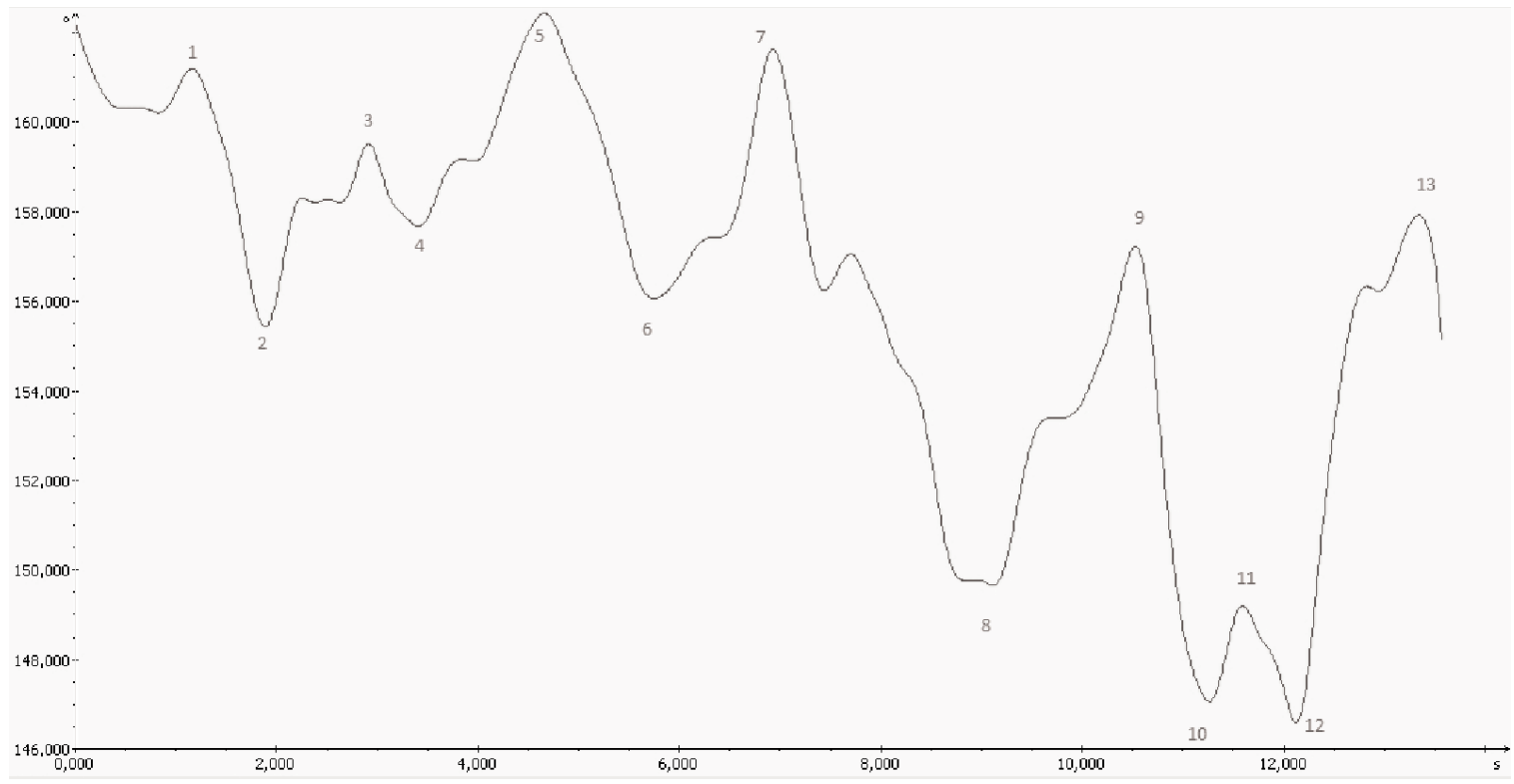

Obr. 7. Graf zobrazujicí změny velikosti úhlu „zápěstí-rameno - kyčel“

Tab. 2. Hodnoty úhlu ,zápěstí - rameno - kyčel“ přislušné k jednotlivým číselným označením v grafu na obrázku c. 3 .

\begin{tabular}{|c|c|c|}
\hline & hodnota úhlu $\left(^{\circ}\right.$ ) & Čas (s) \\
\hline $\mathbf{1}$ & 161,206 & 1,159 \\
\hline $\mathbf{2}$ & 155,439 & 1,889 \\
\hline $\mathbf{3}$ & 159,511 & 2,908 \\
\hline $\mathbf{4}$ & 157,684 & 3,408 \\
\hline $\mathbf{5}$ & 162,437 & 4,657 \\
\hline $\mathbf{6}$ & 156,070 & 5,746 \\
\hline $\mathbf{7}$ & 161,627 & 6,925 \\
\hline $\mathbf{8}$ & 149,659 & 9,114 \\
\hline $\mathbf{9}$ & 157,229 & 10,533 \\
\hline $\mathbf{1 0}$ & 147,063 & 11,262 \\
\hline $\mathbf{1 1}$ & 149,193 & 11,592 \\
\hline $\mathbf{1 2}$ & 146,591 & 12,122 \\
\hline $\mathbf{1 3}$ & 157,925 & 13,341 \\
\hline
\end{tabular}


Z vybraných hodnot změn úhlu jsme sestavili krabicový graf (obr. 8), který nám znázorňuje maximální a minimální velikosti úhlů a také medián.

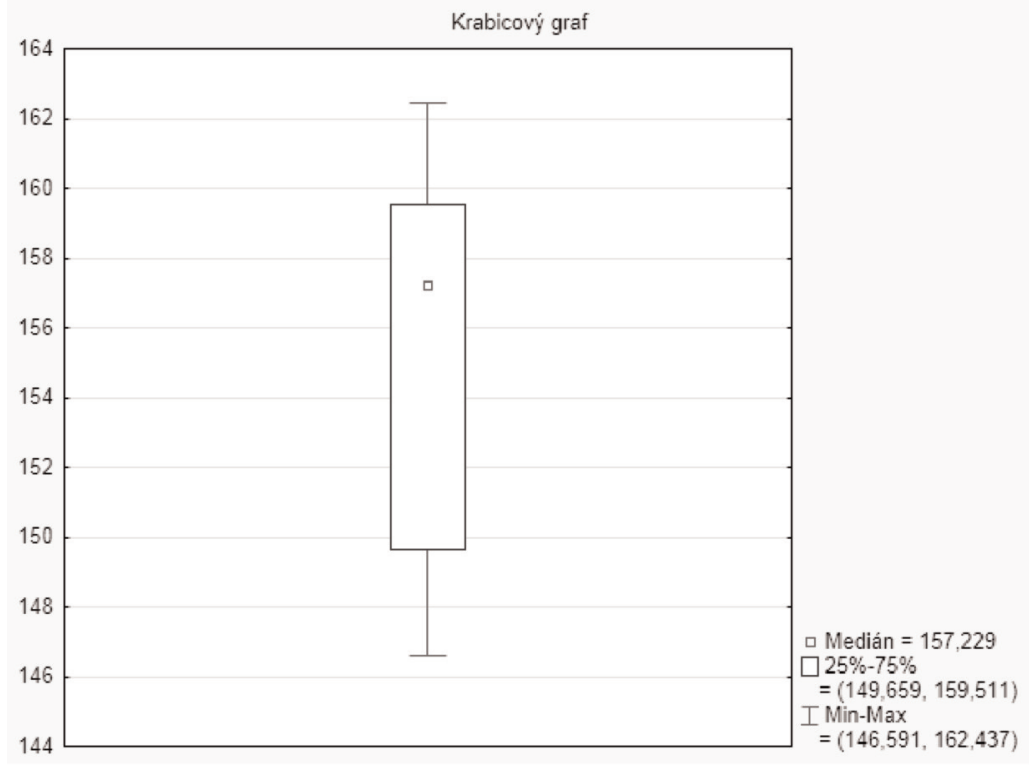

Obr. 8. Krabicový graf pro vizualizaci rozložení dat ve zkoumaném vzorku

Ze zjištěných údajů jsme vyhodnotili, že maximální úhel v segmentech „zápěstí - rameno - kyčel“ byl $162,437^{\circ}$ a minimální $146,591^{\circ}$. Medián má hodnotu $157,229^{\circ}$. Dále se opět zabýváme pouze mikrofázemi $\mathrm{s}$ výraznějšími změnami úhlu.

\section{1-2}

V časovém úseku v tabulce 2 od $1,159 \mathrm{~s}$ do $1,889 \mathrm{~s}$, kdy dochází k poklesu velikosti daného, vykazují aktivní práci tyto ze sledovaných svalů:
m. deltoideus (p. scapularis)
m. extensor carpi ulnaris
m. triceps brachii
$m$. rectus abdominis
m. erector spinae

$0,924-3,028 \mathrm{~s}$

$1,494-1,643 \mathrm{~s}$

$0,089-10,666 s$

$0,500-1,386 s$

$0,940-2,555 s$ 


\section{7-8}

Během delšího časového úseku 6,925 - 9,114 s, dochází k největšímu dosavadnímu poklesu v daném úhlu, z $161,627^{\circ}$ až na $149,659^{\circ}$. Zapojení svalů bylo následovně:

\section{m. deltoideus (p. clavicularis) \\ m. deltoideus (p. scapularis)}

m. flexor carpi radialis

m. extensor carpi ulnaris

\section{m. biceps brachii}

m. triceps brachii

m. rectus abdominis

m. erector spinae

$$
\begin{aligned}
& \mathbf{7 , 9 6 0}-\mathbf{1 0 , 0 4 7} s \\
& \mathbf{6 , 9 1 0}-\mathbf{7 , 9 1 5} s \\
& \mathbf{8 , 0 2 2}-\mathbf{8 , 3 9 4} \mathrm{s} \\
& \mathbf{8 , 5 6 1}-\mathbf{8 , 9 9 8} \mathrm{s} \\
& \mathbf{8 , 2 3 4}-\mathbf{8 , 2 9 5} \mathrm{s} \\
& \mathbf{8 , 3 4 2}-\mathbf{8 , 4 3 0} \mathrm{s} \\
& \mathbf{8 , 4 6 3}-\mathbf{8 , 8 7 2} \mathrm{s} \\
& \mathbf{8 , 9 8 3}-\mathbf{9 , 0 4 4} \mathrm{s} \\
& \mathbf{6 , 8 0 0}-\mathbf{7 0 9 3} \mathrm{s} \\
& \mathbf{7 , 2 3 4}-\mathbf{7 , 4 8 6} \mathrm{s} \\
& \mathbf{7 , 7 7 6}-\mathbf{7 , 8 4 8} \mathrm{s} \\
& \mathbf{8 , 2 1 3}-\mathbf{8 , 4 3 6} \mathrm{s} \\
& \mathbf{8 , 4 8 9}-\mathbf{9 , 0 0 2} \mathrm{s} \\
& \mathbf{7 , 1 2 7}-\mathbf{7 , 1 8 6} \mathrm{s} \\
& \mathbf{7 , 3 2 1}-\mathbf{7 , 8 5 8} \mathrm{s} \\
& \mathbf{0 , 0 8 9}-\mathbf{1 0 , 6 6 6} \mathrm{s} \\
& \mathbf{5 , 2 1 3}-\mathbf{7 , 5 5 3} \mathrm{s} \\
& \mathbf{7 , 7 7 5}-\mathbf{1 0 , 3 5 6} \mathrm{s} \\
& \mathbf{6 , 9 0 4}-\mathbf{7 , 8 8 5} \mathrm{s} \\
& \mathbf{8 , 3 1 4}-\mathbf{8 , 3 6 7} \mathrm{s} \\
& \mathbf{8 , 8 8 3}-\mathbf{8 , 9 1 6} \mathrm{s}
\end{aligned}
$$

8-9

V časovém rozmezí 9,114 - 10,533s dochází k opětovnému naprrímení probanda na $157,229{ }^{\circ}$ za práce $m$. deltoideus ( $p$. clavicularis) a $m$. deltoideus (p. scapularis):

m. deltoideus (p. clavicularis)

m. deltoideus (p. scapularis)

$$
\begin{aligned}
& 7,960-10,047 s \\
& 10,495-10,541 s
\end{aligned}
$$

$$
\begin{aligned}
& 9,401-9,598 s \\
& 9,637-9,840 s \\
& 10,003-11,598 s
\end{aligned}
$$

V úsecích č. 1 a 2 vidíme, že proband využívá setrvačnost ve stoji na rukou, kdy se neaktivizuje $m$. deltoideus (p. clavicularis). Ten začíná pracovat až od třetího úseku, což poukazuje na fakt, že pohyby v tomto kloubu jsou kontrolovány aktivní prací $m$. deltiodeus.

Největší úbytek velikosti úhlu je v úseku 7-8. Ve spojitosti se svalovou prací můžeme vidět přerušování akce u všech sledovaných svalů, nejvíc však u $m$. flexor carpi radialis a $m$. extensor carpi ulnaris, efekt na výslednou změnu úhlu ale tyto akce nemají, protože při podobné akci svalů v ostatních úsecích to nemá na změnu úhlu stejný efekt.

\section{DISKUZE}

Největší aktivitu jsme zaznamenali u deltových svalů a svalů předloktí. Tyto výsledky logicky odpovídají skutečnosti, že proband využíá dominantně 3 segmentální strategii balancování - ruce-paže-trup s dolními končetinami, což dokazují i výsledky úhlových změn v jednotlivých kloubech, jak je demonstrováno na obr. 6 a 8. Pohyby v kloubu ramenním jsou dominantní, prováděny ve větším rozsahu $\left(149^{\circ}-159^{\circ}\right)$ na rozdíl od pohybů v kloubu kyčelním, kde sice došlo ke dvěma výraznějším změnám, ale ostatní výchylky jsou ve srovnání

Zatímco svaly předloktí, flexor m. carpi radialis a m. extensor carpi ulnaris spolu se svaly m. triceps brachii a m. biceps brachii se aktivně podílejí na procesu balancování stoje na rukou po celou dobu setrvání probanda 
v této poloze, deltoideus clavicularis, deltoideus scapularis jsou aktivní pouze v některých momentech.

Překvapující bylo zjištění, že při tomto procesu se aktivně nepodílí svaly m. erector spinae, jak je patrno z obr.1. Domnívali jsme se, že může jít o chybu měření, proto jsme provedli měření kontrolní u jiné pohybové struktury, kdy cvičenec přechází zvolna ze vzporu stojmo rozkročného do stoje na rukou. Zde jsme zjistili aktivní činnost zádového svalstva při vzestupné fázi, ale v okamžiku dosažení polohy stoje na rukou se opakovala situace s předchozího testu, ztráta aktivity zádového svalstva. Jeho funkci, dle našeho názoru, přebírá vnitřní stabilizační systém, jehož aktivitu povrchovou elektromyografií však nejsme schopni měřit. Z těchto výsledků vyplývá, že nejčastější informace poskytované cvičencům ,zpevni břicho a záda“ nejsou zcela opodstatněné a je nutno se ve funkční př́ípravě zaměřit právě na cvičení aktivující činnost vnitřního stabilizačního systému, která jsou hlavně u cvičenců v mladším věku opomíjená.

\section{ZÁVĚRY}

Většina autorů analyzovala stoj na rukou pouze z jednoho pohledu. Nejčastěji to byla stabilometrie nebo 3D analýza, Nám šlo o co možná nejkomplexnější pohled na danou problematiku, proto jsme zvolili nejen stabilometrii a 3D analýzu, ale doplnili jsme i o EMG měření, což nám může poskytnout širší pohled na danou problematiku. Již tato príípadová studie nám poskytla zajímavé informace a to hlavně měření EMG. Svaly, na které je kladen při nácviku a funkční př́pravě velký důraz, $\mathrm{m}$. erector spinae a m. rectus abdominis v podstatě nepracují nebo pracují pouze v omezeném rozsahu. Toto zjištění můžeme zdůvodnit i faktem, že cvičenec, který nevyniká při silových testech, může být ve stoji na rukou stabilnější než gymnasta silově lépe vybaven. Tímto směrem bychom měli zaměřit inovaci metodiky nácviku stoje na rukou. Rozvoj vnitřní stabilizačního systému bývá hlavně u mladších cvičenců často zanedbáván, i když jak se ukazuje, hraje nezastupitelnou roli při provádění základních pohybových struktur, jakým stoj na rukou bezesporu je. Můžeme doporučit cviky na rozvoj síly vnitřního stabilizačního systému, kde se jedná se o hluboko uložené stabilizační svaly v břišní stěně (př́ícný sval břišní (musculus transversus abdominis), vnitřní šikmý břišní sval (musculus obliquus internus abdominis), paravertebrální svalstvo $\mathrm{v}$ okolí páteře.

Příklady cvičení:

1.

- $\quad$ leh, vzpažit, mírný ohnutý předklon a současně přednožit poníž, výdrž v této poloze

- $\quad$ půlobratem leh na P/L boku, vzpažit, mírný úklon a zvednout nohy nad podložku, výdrž v této poloze

- $\quad$ půlobratem leh na břiše, vzpažit, mírný hrudní záklon a zanožit, výdrž v této poloze

2.

- $\quad$ vzpor ležmo vysazeně roznožný, ruce podál, současně diagonálně zvedneme $\mathrm{P} / \mathrm{L}$ horní a L/P dolní končetinu max. $10 \mathrm{~cm}$ nad podložku.

- $\quad$ výdrž v této poloze.

\section{LITERATURA}

Asseman, F., Caron, O. \& Crémieux, J. (2004). Is there a transfer of postural ability from specific to unspecific postures in elite gymnasts? Neuroscience Letters, vol. 358, no. 2, p. 83-86.

Gautier, G., Thouvarecq, R. \& Chollet, D. (2007). Visual and postural control of an arbitrary posture: the handstand. Journal of Sports Sciences, vol. 25, no. 11, p. 1271-1278.

Kerwin, D. G. \& Trewartha, G. (2001). Strategies for maintaining a handstand in the anterior-posterior direction. Med. Sci. Sports Exerc., vol. 33, no. 7, p. 1182-1188.

Nashner, L. M. \& Mccollum, G. (1985). The organisation of human postural movements: A formal basis and experimental synthesis. Behavior and Brain Sciences, vol. 8, p. $135-172$.

Sebera, M., et al. (2007). SIMI Motion - 3D biomechanická analýza. Studia Sportiva, vol. 1, p. 26-31.

Slobounov, S. M. \& Newell, K. M. (1996). Postural dynamics in upright and inverted stances. Journal of Applied Biomechanics, vol. 12, p. 185 - 196.

Sobera, M. (2007). Maintaning body balance in extreme positions. Biology of Sport, vol. 24, no. 1, p. 81-88. Yeadon, M. R. \& Trwartha, G. (2003). Control Strategy for a Hand Balance. Motor control, vol. 7, no. 4, p. $411-430$. 